\title{
Antinociceptive Effects of Pomegranate (Punica granatum L.) Juice and Seed Extracts on Acute Corneal Pain in Mice
}

\author{
Zahra Malek' ${ }^{1}$, Shirin Mansoori Dara1, Mahsa Hadipour Jahromy²* \\ ${ }^{1}$ Medical Sciences Research Center, Faculty of Medicine, Tehran Medical Sciences Branch, Islamic Azad \\ University, Tehran, Iran \\ ${ }^{2}$ Department of Pharmacology, Medical Sciences Research Center, Faculty of Medicine, Tehran Medical \\ Sciences Branch, Islamic Azad University, Tehran, Iran \\ Email: ${ }^{\text {jahromymh@yahoo.com }}$
}

Received 9 March 2014; revised 5 April 2014; accepted 10 April 2014

Copyright (C) 2014 by authors and Scientific Research Publishing Inc. This work is licensed under the Creative Commons Attribution International License (CC BY). http://creativecommons.org/licenses/by/4.0/ (c) (i)

\section{Abstract}

In the present study, the antinociceptive effects of acute $(2,4$ and $6 \mathrm{ml} / \mathrm{kg})$ and chronic $(1,2$ and 3 $\mathrm{ml} / \mathrm{kg}$ for 14 days) oral administration of pomegranate (Punica granatum L.) juice and seed extract with or without morphine and naloxane were investigated on hypertonic saline-induced acute corneal pain perception in mice. The number of eye wipes with a forelimb was counted for a period of 30 seconds as the criterion for pain assessment. Acute oral administration of the extract (at $6 \mathrm{ml} / \mathrm{kg}$ dose, once) and chronic oral administration (at 2 and $3 \mathrm{ml} / \mathrm{kg}$ for 14 days each) significantly decreased the number of eye wipes after subcutaneous injection of morphine ( $2 \mathrm{mg} / \mathrm{kg}, \mathrm{sc})$, naloxone $(2 \mathrm{mg} / \mathrm{kg}, \mathrm{sc})$ and normal saline $(2 \mathrm{mg} / \mathrm{kg}, \mathrm{sc})$ compared with control $(\mathrm{p}<0.05)$. The morphine-induced antinociception was significantly improved by both acute and chronic oral administrations of pomegranate extract $(\mathrm{p}<0.05)$. Naloxone $(2 \mathrm{mg} / \mathrm{kg}, \mathrm{sc})$ did not reverse the antinociceptive effects of acute (at $6 \mathrm{ml} / \mathrm{kg}$ dose, once, oral) and chronic (at 2 and $3 \mathrm{ml} / \mathrm{kg}$ for $14 \mathrm{days}$ each) treatments. These findings demonstrate that acute high-dose and long-term lower-dose of pomegranate juice and seed extract can decrease acute corneal pain and improve morphine-induced antinociception in mice.

\section{Keywords}

Punica granatum, Morphine, Naloxone, Acute Corneal Pain, Mice

\footnotetext{
${ }^{*}$ Corresponding author.
}

How to cite this paper: Malek, Z., Dara, S.M. and Jahromy, M.H. (2014) Antinociceptive Effects of Pomegranate (Punica granatum L.) Juice and Seed Extracts on Acute Corneal Pain in Mice. World Journal of Neuroscience, 4, 99-105. 


\section{Introduction}

Pomegranate, Punica granatum L., has a wide range of therapeutic effects that may be attributed to anti-oxidant, anti-carcinogenic, and anti-inflammatory mechanisms. Clinical application of various extracts (peel, bark, fruit, seed, pulp, and flower) of pomegranate has been focused on treatment and prevention of cancer, cardiovascular diseases and diabetes. Other benefits are observed in viral infections [1] oral bacterial infections, erectile dysfunction, Alzheimer's disease [2] osteoarthritis [3] and obesity [4].

During the last decades, potential analgesic effects of folk medicinal plants have been elicited. Antinociceptive effects of many Persian medicinal plants, olive (Olea europaea L.) [5], ginger (Zingiber officinale Roscoe) [6], saffron (Crocus sativus L.) [7], oleaster (Elaeagnus angustifolia) [8], fennel (Foeniculum vulgare) [9] and black cumin seed (Nigella sativa L.) were investigated in experimental studies and even in clinical trials [10].

The cornea is used for study of nociception in the trigeminal system because corneal nociceptive receptors have a wide representation in the trigeminal ganglion through the ophthalmic branch of trigeminal nerve. It has been shown that nociceptive neurons in trigeminal nucleus respond when $5 \mathrm{M} \mathrm{NaCl}$ is applied to the corneal surface [11] [12]. The eye wiping with a forelimb during acute hypertonic saline-induced pain (one $40 \mu \mathrm{l}$ drop of $5 \mathrm{M} \mathrm{NaCl}$ solution topically on the corneal surface) has been introduced as a criterion for assessment of acute trigeminal pain animal models as a behavioral method [13] [14].

This study was designed to evaluate the probable antinociceptive role of the acute and chronic oral administrations of pomegranate juice and seed extract on hypertonic saline-induced acute corneal pain perception in mice and compared it with analgesic opioid system to identify the mechanism.

\section{Materials and Methods}

\subsection{Animals}

Male adult mice weighing $25 \pm 5$ g (Pasteur Institute, Karaj Production and Research Center, Iran) were used in this study. The animals were randomly divided into 36 groups of ten each. Animals housed under the following laboratory conditions: temperature $22^{\circ} \mathrm{C} \pm 1^{\circ} \mathrm{C}$, humidity $40 \%-60 \%, 12: 12-\mathrm{L} / \mathrm{D}$ cycle, lights on at 07:00 h. Mice were maintained in polyethylene cages with food and water available ad libitum. Experiments were carried out between 10:00 and 14:00 h in the animal testing room. Mice were treated by the current regulations of Medical Science Research Center, Tehran Medical Branch, Islamic Azad University, Tehran, Iran, in accordance with the National Institutes of Health $(\mathrm{NIH})$ Guidelines for Care and Use of Laboratory Animals.

\subsection{Drugs and Design of the Study}

Pomegranates (Punica granatum L.), was collected by one of the colleagues from the agriculture garden, in Saveh, a city where known to have one of the best pomegranate native in Iran. Then washed, chilled to $4^{\circ} \mathrm{C}$, and stored. The seeds of the fruit containing the intact juice sacs were manually separated from the pericarp, and the whole juice extracted by the aid of electric juicer so that seeds break. Then filtered and stored in clean jars in fridge.

The pomegranate juice and seed extract was provided at doses of 2, 4 and $6 \mathrm{ml} / \mathrm{kg}$ for acute and at doses of 1 , 2 and $3 \mathrm{ml} / \mathrm{kg}$ for chronic oral administrations. Drugs used in the present study included morphine sulfate (Temad, Tehran, Iran) and naloxone hydrochloride (Tolid-Darou, Tehran, Iran) were dissolved in normal saline. Normal saline (control), morphine ( $2 \mathrm{mg} / \mathrm{kg})$ and naloxone $(2 \mathrm{mg} / \mathrm{kg})$ in a constant volume of $0.2 \mathrm{ml}$ per mouse were injected subcutaneously (sc) in the back of neck using insulin needle [12]. In acute treatments, the extract at 2, 4 and $6 \mathrm{ml} / \mathrm{kg}$ dose was administered orally on a single occasion and in chronic treatments, oral administration of extract at 1,2 and $3 \mathrm{ml} / \mathrm{kg}$ dose was given at once daily over a period of 14 days. Control groups of both acute and chronic treatments, distilled water were administrated orally. Oral administrations of distilled water and the extract were performed over a period of between 30 - $40 \mathrm{~s}$ using a feeding-needle (gavage) 1 ml syringe. Firstly, effects of morphine, naloxone and naloxone prior to morphine on number of eye-wiping/30 sec in three separate groups were examined before topical application of a $5 \mathrm{M} \mathrm{NaCl}$ in mice. Second, each dosage of acute and chronic treatments was included 3 replicates and 3 control groups. All 3 replicates of one constant dose were orally administered the same dose of extract while control groups received distilled water. In combined treatment, naloxane and morphine were injected sc to a pair of treatment and control groups of each dose, separately. Morphine, naloxane and saline were injected sc over a period of between 20 - 30 min after oral administration of extract. 


\subsection{Corneal Nociception}

Acute corneal nociception was induced $1 \mathrm{~h}$ after the last oral administration of extract. Briefly, mice were placed in a vacant cage. After a 15 min adaptation period, each mouse was handled smoothly, one $40 \mu \mathrm{l}$ drop of $5 \mathrm{M}$ $\mathrm{NaCl}$ solution was applied locally on the corneal surface using a fine dropper, and then the number of eye wipes performed with the ipsilateral forepaw was counted during the first $30 \mathrm{~s}$. As control, one drop of $0.15 \mathrm{M} \mathrm{NaCl}$ solution was applied [11].

\subsection{Statistical Analysis}

To evaluate significance differences among treatment groups versus control groups, a one-way analysis of variance (ANOVA) followed by Duncan's test were applied using ORIGIN 6 statistical software. All data were expressed as the mean \pm standard error of the mean (SEM).

\section{Results}

All of tested animals reacted to locally applied $5 \mathrm{M} \mathrm{NaCl}$ solution. Whereas, none of them reacted to topical application of $0.15 \mathrm{M} \mathrm{NaCl}$ solution (Were not shown in the figure). The number of eye wipes induced by topical application of $5 \mathrm{M} \mathrm{NaCl}$ solution decreased significantly after the sc injection of morphine at $2 \mathrm{mg} / \mathrm{kg}$ dose (p < $0.05)$. The sc injection of naloxone $(2 \mathrm{mg} / \mathrm{kg}$, sc) did not change corneal pain, whereas pre-treatment with naloxone $(2 \mathrm{mg} / \mathrm{kg}$, sc) prior to the administration of morphine $(2 \mathrm{mg} / \mathrm{kg}$, sc) prevented antinociceptive effect of morphine significantly ( $<<0.05$; Figure 1$)$.

In the acute separate treatments with the pomegranate extract, doses of 2 and $4 \mathrm{ml} / \mathrm{kg}$, produced no changes in corneal pain, to be statistically significant. Whereas, acute separate dose of $6 \mathrm{ml} / \mathrm{kg}$, significantly decreased the number of eye wipes $(\mathrm{p}<0.05)$. In addition, acute combined treatments of the pomegranate extract $(2,4$ and 6 $\mathrm{ml} / \mathrm{kg}$, once, po) with morphine ( $2 \mathrm{mg} / \mathrm{kg}$, sc), significantly decreased the number of eye wipes (p $<0.05)$. Naloxone (2 mg/kg, sc) did not inhibit the antinociceptive effect of the acute $(6 \mathrm{ml} / \mathrm{kg}$, once, po) treatments of the pomegranate extract on suppressing corneal pain (Table 1). Results from 2 and $4 \mathrm{ml} / \mathrm{kg}$ doses were not shown in the figure.

In the chronic separate treatments of the pomegranate extract, dose of $1 \mathrm{ml} / \mathrm{kg}$ had no significant effect, whereas chronic (2 and $3 \mathrm{ml} / \mathrm{kg}, 14$ days, po) and the chronic combined treatment of the extract (1, 2 and $3 \mathrm{ml} / \mathrm{kg}, 14$ days, po), with morphine $(2 \mathrm{mg} / \mathrm{kg}$, sc) significantly decreased the number of eye wipes ( $\mathrm{p}<0.05)$. Naloxone (2 $\mathrm{mg} / \mathrm{kg}, \mathrm{sc}$ ) did not inhibit the antinociception that was induced by chronic (2 and $3 \mathrm{ml} / \mathrm{kg}, 14$ days, po) treatments of the pomegranate extract (Figure 2). Results from $1 \mathrm{ml} / \mathrm{kg}$ dose were not shown in the figure. There were no significant findings, among the extract administration at different dose and count of eye-wiping.

\section{Discussion}

The present study provides evidence indicating that in mice with corneal pain induced by saline acute and chronic oral administration of the pomegranate juice and seed extract not only has some antinociceptive effects,

Table 1. Effect of acute oral administrations of pomegranate $(6 \mathrm{ml} / \mathrm{kg})$ on hypertonic saline-induced corneal pain after subcutaneous injection of morphine (2 mg/kg), naloxone (2 mg/kg) and normal saline compared with control, that is wat + sal (mean \pm SEM; $n=10$ mice per group, significance level $=\mathrm{p}^{*}<0.05$ ) (mor: morphine; nal: naloxone; po: oral administrations; pom: pomegranate; sal: saline; sc: subcutaneous; wat: water).

\begin{tabular}{cc}
\hline Groups & Mean \pm SEM No Eye Wipes/30 sec \\
\hline pom + sal & $14 \pm 0.8^{*}$ \\
wat + sal & $16.1 \pm 1.1$ \\
pom + mor & $13.3 \pm 1.2^{*}$ \\
wat + mor & $13.8 \pm 1.1^{*}$ \\
pom + nal & $14.6 \pm 1.8^{*}$ \\
wat + nal & $17.3 \pm 1.6$ \\
\hline
\end{tabular}




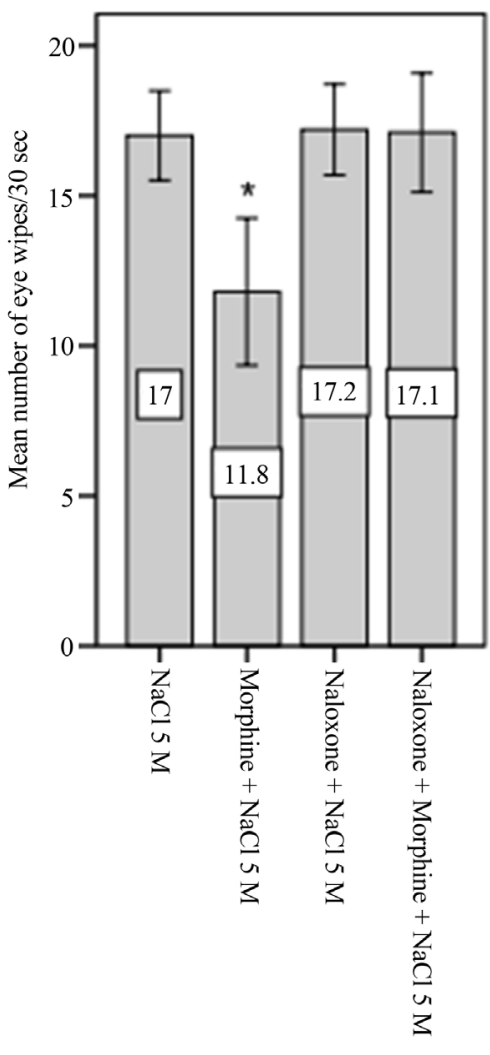

Group

Error bars: $+/-2 \mathrm{SE}$

Figure 1. Effect of morphine, naloxone and naloxone prior to morphine on number of eye-wiping/30 sec (mean \pm SEM; $n=10$ mice per group, significance level $={ }^{*} \mathrm{p}<0.05$ when compared to the first, $\mathrm{NaCl} 5 \mathrm{M}$ group) after topical application of a $5 \mathrm{M} \mathrm{NaCl}$ in mice. $\mathrm{NaCl}$ : sodium chloride; SE: standard error.

but also can improve morphine-induced antinociception. Moreover, naloxone does not inhibit the antinociceptive effect of pomegranate in both acute and chronic regimens.

Morphine-induced analgesia is through $\mu$-opioid receptors ( $\mu \mathrm{ORs}$ ) in spinal and supraspinal regions of the CNS and naloxone as a competitive antagonist of $\mu \mathrm{OR}$, antagonizes the analgesic effect of morphine [15] [16]. In previous nociceptive assays on murine models, morphine was ineffective in visceral nociception in mice lacking $\mu$-opioid receptors [17]. Ophthalmic application of morphine as well as intracerebroventricular (icv) injection, prior to corneal stimulation, both can attenuate hyperalgesia which is prevented by naloxone [18] [19]. Moreover, icv injections of histamine and oxytocin decreased nociception and increased the antinociceptive effect of morphine [11] [20]. According to previous studies, the antinociceptive activity of morphine is influenced by many factors: the nociceptive test, gonadal steroid hormones and strain of the animal [21]-[23].

In the model of neuron injury-induced trigeminal neuropathic pain, results have shown the effects of morphine on nociceptor-evoked activation of central trigeminal neurons for attenuating trigeminal pain [24]. As another model of acute trigeminal pain, antinociceptive activity of morphine has been evaluated using acute hypertonic saline-induced corneal pain (one $40 \mu \mathrm{l}$ drop of $5 \mathrm{M} \mathrm{NaCl}$ solution topically on the corneal surface) [11] [25]. These studies demonstrate that morphine attenuates the pain response and that morphine-induced antinociceptive effect is through a naloxone-sensitive mechanism in acute corneal pain. 


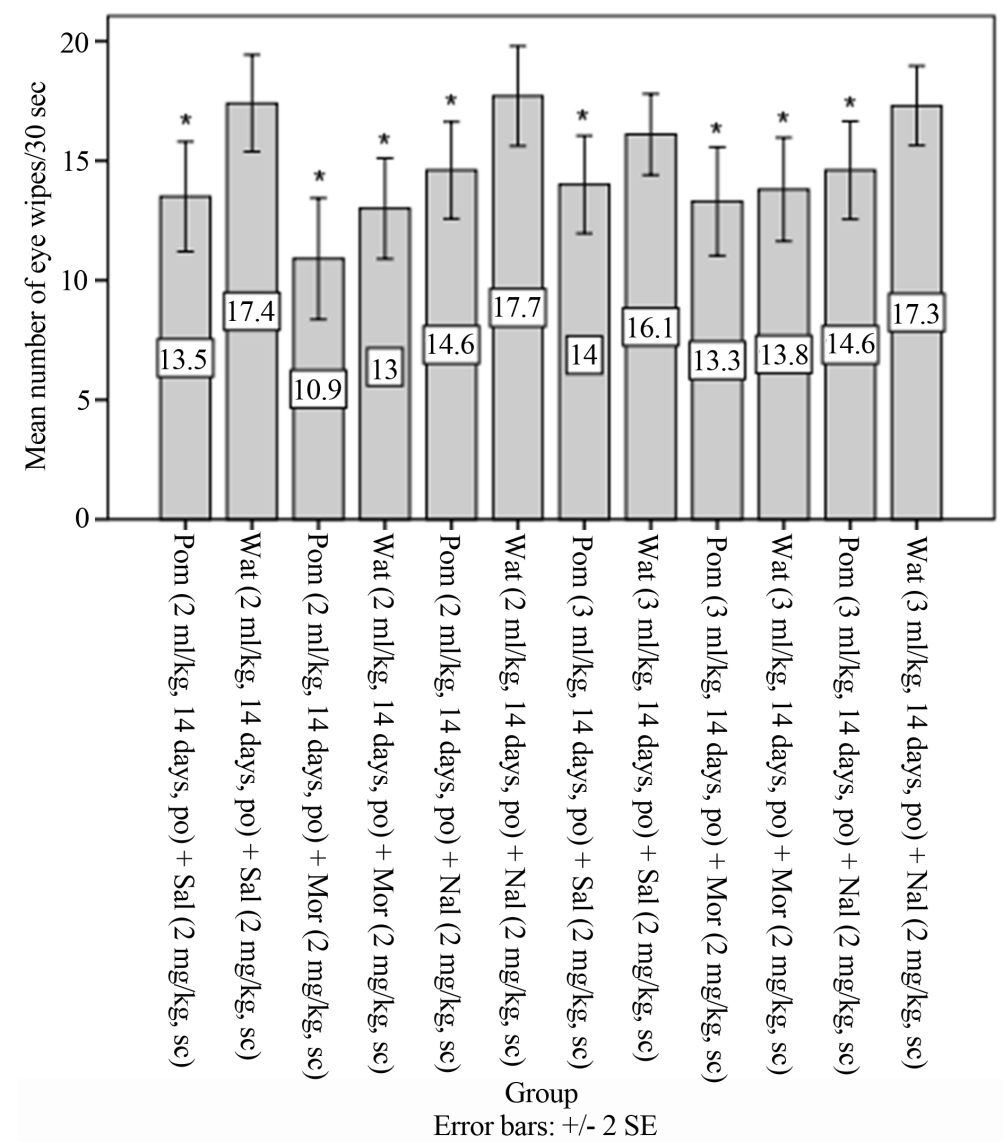

Figure 2. Effect of chronic oral administrations of pomegranate on hypertonic saline-induced corneal pain after subcutaneous injection of morphine, naloxone and normal saline compared with control, that is wat+sal (mean \pm SEM; $n$ $=10$ mice per group, significance level $={ }^{*} \mathrm{p}<0.05$ ). Mor: morphine; Nal: naloxone; po: oral administrations; Pom: pomegranate; Sal: saline; sc: subcutaneous; SE: standard error; Wat: water.

Pomegranate has a variety of therapeutic benefits that may be attributed to its antioxidant capacity [26]. It has been shown that antioxidant components of pomegranate fruit and seed extracts scavenge free radicals, e.g., hydroxyl $(\cdot \mathrm{OH})$ and superoxide $\left(\mathrm{O}_{2} \cdot-\right)$ radicals; [27] and decrease macrophage oxidative stress in animals and increase plasma antioxidant capacity in elderly humans [2]. These polyphenolic flavonoid antioxidants enhance the biological actions of naturally produced nitric oxide (NO) in vivo. In fact, antioxidants stabilize NO and prolong cellular concentration of NO by protecting it against free radical destruction, e.g. by reactive oxygen species (ROS) [28]-[30].

$\mathrm{NO}$, as a signaling molecule is synthesized by the nitric oxide synthase (NOS) that catalyzes the reaction of molecular oxygen with the amino acid substrate L-arginine (L-Arg) to produce NO [31]. NO acts as a modulator in spinal cord and dorsal root ganglia via nociceptive pathways [32] and mediates neuropathic pain. Some studies have shown that NOS inhibitors attenuate the antinociceptive effects of morphine and morphine tolerance/ dependence [33], in contrast others have reported that NOS inhibition augments morphine-induced antinociception in animal experimental study [34]. Therefore, it seems that NO modulates the morphine related analgesia by either enhancing or reducing antinociception [32].

Previous studies have elicited that the endogenous NO is involved in the antinociceptive effects of morphine. However, the precise mechanism by which NO system enhances the opioid-mediated analgesia has not been completely clarified yet. Although speculative, it seems that in the present study pomegranate antioxidants that may have protected NO from free radical destruction may have enhanced morphine analgesia. From this point of view, ineffective role of naloxone to inhibit the antinociceptive effect of pomegranate may be attributable to ab- 
sence of naloxone in the NO-dependent antinociceptive mechanisms or simply refer to a distinct mechanism of pomegranate for antinociception which is irrelevant to opioid receptors.

\section{Conclusion}

In conclusion, although the present study elucidates analgesic property of pomegranate in mice with corneal pain, the precise mechanism involved in pomegranate-induced antinociception and the contribution of the endogenous analgesic opioid system in this mechanism are unknown. Other activities on inflammatory mediators such as cyclooxygenase and lipooxygenase, cytokines and free radicals can be considered and investigated in future studies.

\section{References}

[1] Miguel, M.G., Neves, M.A. and Maria D.A. (2010) Pomegranate (Punica granatum L.): A Medicinal Plant with Myriad Biological Properties-A Short Review. Journal of Medicinal Plants Research, 4, 2836-2847.

[2] Jurenka, J.S. (2008) Therapeutic Applications of Pomegranate (Punica granatum L.): A Review. Alternative Medicine Review, 13, 128-144.

[3] Hadipour-Jahromy, M. and Mozaffari-Kermani, R. (2010) Chondroprotective Effects of Pomegranate Juice on Monoiodoacetate-Induced Osteoarthritis of the Knee Joint of Mice. Phytotherapy Research, 24, 182-185.

[4] Rahimi, H.R., Arastoo, M. and Ostad, S.N. (2012) A Comprehensive Review of Punica granatum (Pomegranate) Properties in Toxicological, Pharmacological, Cellular and Molecular Biology Researches (Review). International Journal of Production Research, 11, 385-400.

[5] Esmaeili-Mahani, S., Rezaeezadeh-Roukerd, M., Esmaeilpour, K., Abbasnejad, M., Rasoulian, B., Sheibani, V., Kaeidi, A. and Hajializadeh, Z. (2010) Olive (Olea europaea L.) Leaf Extract Elicits Antinociceptive Activity, Potentiates Morphine Analgesia and Suppresses Morphine Hyperalgesia in Rats. Journal of Ethnopharmacology, 132, 200-205. http://dx.doi.org/10.1016/j.jep.2010.08.013

[6] Sepahvand, R., Esmaeili-Mahani, S., Arzi, A., Rasoulian, B. and Abbasnejad, M. (2010). Ginger (Zingiber officinale Roscoe) Elicits Antinociceptive Properties and Potentiates Morphine-Induced Analgesia in the Rat Radiant Heat Tail-Flick Test. Journal of Medicinal Food, 13, 1397-1401. http://dx.doi.org/10.1089/jmf.2010.1043

[7] Hosseinzadeh, H. and Younesi, H.M. (2002). Petal and Stigma Extracts of Crocus sativus L. Have Antinociceptive and Anti-Inflammatory Effects in Mice. BMC Pharmacology, 2, 7-10. http://dx.doi.org/10.1186/1471-2210-2-7

[8] Ahmadiani, A., Hosseiny, J., Semnanian, S., Javan, M., Saeedi, F., Kamalinejad, M. and Saremi, S. (2000). Antinociceptive and Anti-Inflammatory Effects of Elaeagnus angustifolia Fruit Extract. Journal of Ethnopharmacology, 72, 287-292. http://dx.doi.org/10.1016/S0378-8741(00)00222-1

[9] Zendehdel, M., Taati, M., Amoozad, M. and Hamidi, F. (2012). Antinociceptive Effect of the Aqueous Extract Obtained from Foeniculum vulgare in Mice: The Role of Histamine. Iranian Journal of Veterinary Research, 13, 100-106.

[10] Akhondzadeh, S., Tahmacebi-Pour, N., Noorbala, A.A., Amini, H., Fallah-Pour, H., Jamshidi, A.H. and Khani, M. (2005) Crocus sativus L. in the Treatment of Mild to Moderate Depression: A Double-Blind, Randomized and Placebo-Controlled Trial. Phytotherapy Research, 19, 148-151. http://dx.doi.org/10.1002/ptr.1647

[11] Tamaddonfard, E., Khalilzadeh, E., Hamzeh-Gooshchi, N. and Seiednejhad-Yamchi, S. (2008) Central Effect of Histamine in a Rat Model of Acute Trigeminal Pain. Pharmacological Reports, 60, 219-224.

[12] Tamaddonfard, E., Hamzeh-Gooshchi, F. and Hamzeh-Gooshchi, N. (2010) Effect of Curcumin on Morphine-Induced Antinociception in Acute Corneal Pain in Rats. International Journal of Veterinary Research, 4, 127-131.

[13] Tamaddonfard, E. and Hamzeh-Gooshchi, N. (2010). Effects of Subcutaneous and Intracerebroventricular Injection of Physostigmine on the Acute Corneal Nociception in Rats. Pharmacological Reports, 62, 858-863. http://dx.doi.org/10.1016/S1734-1140(10)70345-5

[14] Tamaddonfard, E., Farshid, A.A., Seiednejhad, S. and Morvaridi, A. (2011) Role of the Thalamic Parafascicular Nucleus Cholinergic System in the Modulation of Acute Corneal Nociception in Rats. Veterinary Research Forum, 2, 226-230.

[15] Bohn, L.M., Lefkowitz, R.J. and Caron, M.G. (2002) Differential Mechanisms of Morphine Antinociceptive Tolerance Revealed in (Beta) Arrestin-2 Knock-Out Mice. The Journal of Neuroscience, 22, 10494-10500.

[16] Bilsky, E.J., Bernstein, R.N., Wang, Z., Sadée, W. and Porreca, F. (1996) Effects of Naloxone and D-Phe-Cys-Tyr-DTrp-Arg-Thr-Pen-Thr-NH2 and the Protein Kinase Inhibitors H7 and H8 on Acute Morphine Dependence and Antinociceptive Tolerance in Mice. Journal of Pharmacology and Experimental Therapeutics, 277, 484-490. 
[17] Sora, I., Li, X.F., Funada, M., Kinsey, S. and Uhl, G.R. (1999) Visceral Chemical Nociception in Mice Lacking MuOpioid Receptors: Effects of Morphine, SNC80 and U-50, 488. European Journal of Pharmacology, 366, R3-R5. http://dx.doi.org/10.1016/S0014-2999(98)00933-9

[18] Wenk, H.N., Nannenga, M.N. and Honda, C.N. (2003) Effect of Morphine Sulphate Eye Drops on Hyperalgesia in the Rat Cornea. Pain, 105, 455-465. http://dx.doi.org/10.1016/S0304-3959(03)00260-4

[19] Bereiter, D.A. (1997) Morphine and Somatostatin Analogue Reduce c-fos Expression in Trigeminal Subnucleus Caudalis Produced by Corneal Stimulation in the Rat. Neuroscience, 77, 864-874. http://dx.doi.org/10.1016/S0306-4522(96)00541-6

[20] Arletti, R., Benelli, A. and Bertolini, A. (1993) Influence of Oxytocin on Nociception and Morphine Antinociception. Neuropeptides, 24, 125-129. http://dx.doi.org/10.1016/0143-4179(93)90075-L

[21] Morgan, M.M., Fossum, E.N., Stalding, B.M. and King, M.M. (2006) Morphine Antinociceptive Potency on Chemical, Mechanical, and Thermal Nociceptive Tests in the Rat. Pain, 7, 358-366. http://dx.doi.org/10.1016/j.jpain.2005.12.009

[22] Stoffel, E.C., Ulibarri, C.M. and Craft, R.M. (2003) Gonadal Steroid Hormone Modulation of Nociception, Morphine Antinociception and Reproductive Indices in Male and Female Rats. Pain, 103, 285-302. http://dx.doi.org/10.1016/s0304-3959(02)00457-8

[23] Mogil, J.S., Kest, B., Sadowski, B. and Belknap, J.K. (1996) Differential Genetic Mediation of Sensitivity to Morphine in Genetic Models of Opiate Antinociception: Influence of Nociceptive Assay. Journal of Pharmacology and Experimental Therapeutics, 276, 532-544.

[24] Christensen, D., Gautron, M., Guilbaud, G. and Kayser, V. (1999) Combined Systemic Administration of the Glycine/ NMDA Receptor Antagonist, (+)-HA966 and Morphine Attenuates Pain-Related Behaviour in a Rat Model of Trigeminal Neuropathic Pain. Pain, 83, 433-440. http://dx.doi.org/10.1016/S0304-3959(99)00126-8

[25] Farazifard, R., Safapour, F., Sheibani, V. and Javan, M. (2005) Eye-Wiping Test: A Sensitive Animal Model for Acute Trigeminal Pain Studies. Brain Research Protocols, 16, 44-49. http://dx.doi.org/10.1016/j.brainresprot.2005.10.003

[26] Jurenka, J.S. (2008) Therapeutic Applications of Pomegranate (Punica granatum L.): A Review. Alternative Medicine Review, 13, 128-144.

[27] Noda, Y., Kaneyuki, T., Mori, A. and Packer, L. (2002) Antioxidant Activities of Pomegranate Fruit Extract and Its Anthocyanidins: Delphinidin, Cyanidin, and Pelargonidin. Journal of Agricultural and Food Chemistry, 50, 166-171. http://dx.doi.org/10.1021/jf0108765

[28] Ignarro, L.J., Byrns, R.E., Sumi, D., Nigris, F.D. and Napoli, C. (2006) Pomegranate Juice Protects Nitric Oxide against Oxidative Destruction and Enhances the Biological Actions of Nitric Oxide. Nitric Oxide, 15, 93-102. http://dx.doi.org/10.1016/j.niox.2006.03.001

[29] Nigris, F.D., Williams-Ignarro, S., Lerman, L.O., Crimi, E., Botti, C., Mansueto, G., D’Armiento, F.P., De Rosa, G., Sica, V., Ignarro, L.G. and Napoli, C. (2005) Beneficial Effects of Pomegranate Juice on Oxidation-Sensitive Genes and Endothelial Nitric Oxide Synthase Activity at Sites of Perturbed Shear Stress. Proceedings of the National Academy of Sciences of the United States of America, 102, 4896-4901. http://dx.doi.org/10.1073/pnas.0500998102

[30] Ignarro, L.J. and Napolic, C. (2004) Novel Features of Nitric Oxide, Endothelial Nitric Oxide Synthase, and Atherosclerosis. Current Atherosclerosis Reports, 6, 281-287. http://dx.doi.org/10.1007/s11883-004-0059-9

[31] Villanueva, C. and Giulivi, C. (2010) Subcellular and Cellular Locations of Nitric Oxide Synthase Isoforms as Determinants of Health and Disease. Free Radical Biology and Medicine, 49, 307-316. http://dx.doi.org/10.1016/j.freeradbiomed.2010.04.004

[32] Toda, N., Kishioka, S., Hatano, Y. and Toda, H. (2009) Modulation of Opioid Actions by Nitric Oxide Signaling (Review). Anesthesiology, 110, 166-181. http://dx.doi.org/10.1097/ALN.0b013e31819146a9

[33] Özek, M., Üresin, Y. and Güngör, M. (2003) Comparison of the Effects of Specific and Nonspecific Inhibition of Nitric Oxide Synthase on Morphine Analgesia, Tolerance and Dependence in Mice. Life Sciences, 72, 1943-1951. http://dx.doi.org/10.1016/S0024-3205(03)00100-0

[34] Grover, V.S., Sharma, A. and Singh, M. (2000) Role of Nitric Oxide in Diabetes-Induced Attenuation of Antinociceptive Effect of Morphine in Mice. European Journal of Pharmacology, 399, 161-164. http://dx.doi.org/10.1016/S0014-2999(00)00343-5 